\title{
Antihypoxic Effects of Neuroglobin in Hypoxia-Preconditioned Mice and SH-SY5Y Cells
}

\author{
Guo Shao ${ }^{a, b}$ d Ke-Rui Gong ${ }^{c}$ Jiang Li ${ }^{b} \quad$ Xi-Jin Xu ${ }^{a}$ Cui-Ying Gao ${ }^{c}$ \\ Xian-Zhi Zeng ${ }^{c}$ Guo-Wei Lu $^{b}$ Xia Huo $^{\mathrm{a}}$ \\ ${ }^{a}$ Analytical Cytology Laboratory, Shantou University Medical College, Shantou, and ${ }^{b}$ Institute for Hypoxia \\ Medicine and 'Basic Medical College, Capital Medical University, Beijing, China; ${ }^{\mathrm{d} B i o m e d i c i n e ~ R e s e a r c h ~ C e n t e r ~}$ \\ and Basic Medical College, Baotou Medical College, Baotou, Inner Mongolia
}

\section{Key Words}

Neuroglobin $\cdot$ Hypoxic preconditioning $\cdot$ Mice

\begin{abstract}
This work aims at investigating the neuroprotective effects of neuroglobin ( $\mathrm{Ngb}$ ) in vivo and in vitro. RT-PCR and Western blotting were used to examine Ngb mRNA and protein levels in the mouse cortex after acute and repeated exposure to hypoxia. The CDNAs of mouse Ngb were cloned and transfected into $\mathrm{SH}-\mathrm{SY} 5 \mathrm{Y}$ cells to examine Ngb function in vitro. Expression of Ngb and mRNA was upregulated in the cortex of mice preconditioned by repetitive exposure to hypoxia. Tolerance to hypoxia of Ngb-transformed SH-SY5Y cells was enhanced. These results suggest that $\mathrm{Ngb}$ might be involved in hypoxic preconditioning which protects neurons from hypoxic injury.

Copyright $\odot 2009$ S. Karger AG, Basel
\end{abstract}

\section{Introduction}

Ischemic/hypoxic preconditioning (I/HPC), a prominent neuroprotection against subsequent severe ischemia/hypoxia following sublethal exposure to hypoxia, has been extensively studied [1-4]. This protective effect of I/HPC was first observed in the heart and later in the brain of the gerbil $[4,5]$. It is believed to trigger endogenous cellular adaptation. Due to this special protective effect, I/HPC is believed to be a potential target for a clinical therapeutic approach to cerebral ischemic/hypoxic damage. However, the precise molecular mechanism of I/HPC is unclear. To investigate the molecular mechanism of I/HPC in the brain, we developed a unique autohypoxia-induced HPC mouse model that mimics clinical asphyxia $[1,6]$. Using this model, we have demonstrated that during the development of HPC, there are changes in protein expression and activity $[7,8]$. One prominent feature of cellular adaptation to hypoxia is the increased expression of new proteins contributing to the neuroprotection induced by hypoxia [9]. In addition, there was evidence that inhibition of protein synthesis eliminated the effects of HPC on brain neuroprotection [10].

The newly discovered Ngb is a vertebrate globin primarily localized in nerve cells that can bind oxygen reversibly [11]. Expression of Ngb increases in response to oxygen deprivation which in turn can protect neurons from hypoxia in vitro and in vivo $[12,13]$. Ngb is widely expressed in the cerebral cortex, hippocampus, thalamus, hypothalamus and cerebellum in the animal brain and prominently affected in hypoxia or ischemia [14, 15]. Until now, the biological functions of Ngb have re-

\section{KARGER \\ Fax +41613061234 E-Mail karger@karger.ch} www.karger.com
(C) 2009 S. Karger AG, Base

$1424-862 X / 09 / 0173-0196 \$ 26.00 / 0$

Accessible online at:

www.karger.com/nsg
Xia Huo

Analytical Cytology Laboratory, Shantou University Medical College

22 Xinling Road

Shantou 515031, Guangdong (China)

Tel. +86 7548890 0307, Fax +867548856 6774, E-Mail xhuo@stu.edu.cn 
mained a mystery, but is suspected to have various roles in oxygen transport and sensing, binding and scavenging of nitric oxide, binding with CO [16], and in signal transduction $[17,18]$. Many studies have reported the changes of $\mathrm{Ngb}$ under different hypoxic conditions in vivo and in vitro. However, little is known about changes in Ngb expression in the brain after acute and repeated hypoxia stimulation. This study focused on exploring the possible involvement of $\mathrm{Ngb}$ in neuronal responses during HPC using our auto-hypoxia-induced HPC mouse model and demonstrating its antihypoxic effect in vitro.

\section{Materials and Methods}

\section{Animal Model Reproduction}

Male adult BALB/C mice (body weight 16.0-22.0 g) were randomly divided into three groups: blank control group with no exposure to hypoxia $\left(\mathrm{H}_{0}\right)$, the hypoxia control group exposed to hypoxia once $\left(\mathrm{H}_{1}\right)$, and the hypoxia preconditioning group exposed to 4 runs of hypoxia $\left(\mathrm{H}_{4}\right)$. The experimental conditions and procedures were approved by the Local Institutional Animal Care and Use Committee, and followed the US National Institutes of Health principles for laboratory animal care. The procedure of the hypoxic experiment was performed as previously described $[1,19]$. Briefly, the mouse was placed into a $125-\mathrm{ml}$ jar with fresh air, and the jar was sealed with a rubber plug. The mouse was removed from the jar as soon as the first gasping breath appeared, then it was switched to another fresh-air-containing jar of similar volume. This procedure was performed once (group $\mathrm{H}_{1}$ ) or repeated four times (group $\mathrm{H}_{4}$ ).

\section{RNA Isolation and Semiquantitative Reverse Transcription}

\section{Polymerase Chain Reaction Analysis}

Total RNA was prepared from mouse cortex using the RNAeasy minikit (Qiagen, German Town, Md., USA). Total RNA (1 $\mu \mathrm{g})$ was reverse transcribed with Superscript II reverse transcriptase (Invitrogen, Carlsbad, Calif., USA). One microliter of the resulting cDNAs was subjected to amplification in a total volume of $20 \mu \mathrm{l}$ containing $10 \times$ buffer, $1.5 \mathrm{mmol} / 1 \mathrm{MgCl}_{2}, 0.2 \mathrm{mmol} / \mathrm{l}$ of each dNTP, 1 U Taq polymerase (Takara, Shiga, Japan), and a pair of specific primers $(0.2 \mu \mathrm{mol} / \mathrm{l}$ each). Primers for $\mathrm{Ngb}$ and $\beta$-actin were designed using the Primer Premier 5.0 software, and both sequences were obtained from GenBank: $\beta$-actin forward primer: 5'-GAACGGTGAAGGCGACAG- ${ }^{\prime}, \beta$-actin reverse primer: $5^{\prime}$ TTGGGAGGGTGAGGGACT-3'; Ngb forward, 5'-CTCTGGAACATGGCACTGTC-3', Ngbreverse, 5' -GCACTGGCTCGTCTCTTACT- $3^{\prime}$. The PCR temperature for Ngb was as follows: cycles at $92^{\circ} \mathrm{C}$ for $30 \mathrm{~s}$, at $55^{\circ} \mathrm{C}$ for $30 \mathrm{~s}$, and at $72^{\circ} \mathrm{C}$ for $45 \mathrm{~s}$, total $29 \mathrm{cycles}$, followed by a final extension period at $72^{\circ} \mathrm{C}$ for $7 \mathrm{~min}$. The PCR temperature for $\beta$-actin was: cycles at $92^{\circ} \mathrm{C}$ for $25 \mathrm{~s}$, at $55^{\circ} \mathrm{C}$ for $30 \mathrm{~s}$, and at $72^{\circ} \mathrm{C}$ for $25 \mathrm{~s}$, total 20 cycles, followed by a final extension period at $72^{\circ} \mathrm{C}$ for $5 \mathrm{~min}$. Polymerase chain reaction (PCR) products $(9 \mu \mathrm{l})$ were separated by $1.0 \%$ agarose gel electrophoresis and stained with ethidium bromide. The reverse transcription (RT)-PCR products were $323 \mathrm{bp}$ for $\mathrm{Ngb}$ and $175 \mathrm{bp}$ for $\beta$-actin.
Western Blotting Analysis

Total protein was isolated from mouse cortex or transfected SH-SY5Y cells according to a previously described protocol [20, 21]. The protein concentrations were determined using the bicinchoninic acid (BCA) method. Protein $(40 \mu \mathrm{g})$ was separated by SDS-PAGE (12\%) at $30 \mathrm{~mA}$ for $2.5 \mathrm{~h}$ and then blotted onto a nitrocellulose membrane. The membrane was then incubated for $1 \mathrm{~h}$ in blocking buffer (Tris-buffered saline containing 10\% skimmed milk powder) at room temperature. Next, the membrane was incubated for $16 \mathrm{~h}$ at $4^{\circ} \mathrm{C}$ using a goat anti-neuroglobin polyclonal antibody (Santa Cruz Biotechnology, Santa Cruz, Calif., USA) or a mouse anti- $\beta$-actin monoclonal antibody (Sigma, St. Louis, Mo., USA). Then the membrane was incubated with horseradish-peroxidase-labeled secondary antibodies at room temperature for $1 \mathrm{~h}$. After each incubation, the membrane was thoroughly washed 3 times with Tris-buffered saline containing $0.05 \%$ Tween 20. Protein signals were detected by an electrochemiluminescence detection system (Pierce Biotechnology, Rockford, Ill., USA), in which the membrane was exposed to the detection solution for $5 \mathrm{~min}$.

Cloning of the Ngb and Generation of Expression Vectors

The full-length cDNA encoding the mouse Ngb were cloned according to the laboratory method of Burmester et al. [11]. The stop code of the mouse Ngb cDNA was deleted by PCR and the mouse Ngb cDNA without the stop code was subcloned into a pEGFP-N1 expression vector (Clontech, Palo Alto, Calif., USA) and named pEGFP-Ngb.

\section{Cell Culture and Exposure to Hypoxia}

Cells from the human neuroblastoma cell lines SH-SY5Y were cultured in Dulbecco's modified Eagle's medium (Clontech, USA) supplemented with $10 \%$ fetal bovine serum (Invitrogen, USA), Lglutamine and antibiotics, and incubated in a humidified atmosphere of $5 \% \mathrm{CO}_{2}$ at $37^{\circ} \mathrm{C}$. Ngb could be detected in $\mathrm{SH}-\mathrm{SY} 5 \mathrm{Y}$ cell lines [22]. For exposure to hypoxia, cell culture plates were incubated in a modular incubator chamber and flushed with a gas mixture containing $1 \% \mathrm{O}_{2}$, and $5 \% \mathrm{CO}_{2}$. The duration of hypoxia was $0,2,4,6$, and $8 \mathrm{~h}$.

\section{Cell Transfection and Detection of Cell Survival}

SH-SY5Y cells were plated in 35-m plastic dishes and maintained as described previously [23, 24]. Full-length mouse Ngb cDNA was subcloned into pEGFP-N1 plasmid with green fluorescent protein (GFP). The recombinant plasmid (pEGFP-Ngb) or vector alone (pEGFP-N1) was transfected into SH-SY5Y cells by using Lipofect AMINETM Reagent (Invitrogen Life Technologies, USA), by detecting GFP to confirm the results after $16 \mathrm{~h}$. Transfection efficiency of recombinant plasmid and vector was approximately $25 \%$. The injuries of cells without plasmid were detected by Hoechst 33342 and propidium iodide (PI, staining apoptotic and necrotic cells; live cells stain blue, necrotic or terminally apoptotic cells stain red; early apoptotic cells should not stain red) dyeing after hypoxic exposure at different time points in order to explore the optimal operation time point. Cultures were incubated simultaneously with $5 \mu \mathrm{M}$ Hoechst 33342 and $5 \mu \mathrm{g} / \mathrm{ml}$ PI (both from Sigma) for $15 \mathrm{~min}$ in a water bath at $37^{\circ} \mathrm{C}$. The cell survival ratio with pEGFP-Ngb or pEGFP-N1 was measured as the ratio of counted cells carrying PI-unstained nuclei to counted cells which express GFP. The survival of cells without 
transfected plasmid was measured as the ratio of cells carrying PI-unstained nuclei to all cells counted (each about 2,000 cells). The reaction was visualized using a Leica inverted fluorescent microscope (Germany).

\section{Caspase-3/7 Activity Assay}

Apoptotic activity was measured using Caspase-Glo 3/7 Assay kits (Promega, Madison, Wisc., USA). SH-SY5Y cells were seeded into 24 -well opaque microtiter plates at a density of $4 \times 10^{4} /$ well. After $24 \mathrm{~h}$, the cells were transfected with pEGFP-Ngb or pEGFP$\mathrm{N} 1$ and then exposed to hypoxia just as described previously. Then caspase activity was measured with TD-20/20 Luminometer (Turner Designs, Sunnyvale, Calif., USA) using the CaspaseGlo 3/7 assay kit according to the manufacturer's protocol.

\section{Quantification and Statistics}

The optical density (OD) of bands of PCR products and Western blot were obtained by the Gel-Doc system and analyzed with SigmaGel software (Jandel Scientific, San Rafael, Calif., USA). The data of RT-PCR and Western blot were normalized to $\beta$-actin and presented as relative abundance. All data are expressed as mean \pm SD. Statistical analysis was performed by means of ANOVA and the Tukey test using SPSS 10.0 software (SPSS Inc., Chicago, Ill., USA). $\mathrm{p}<0.05$ was considered to be statistically significant.

\section{Results}

\section{Tolerance of Preconditioning Mice to Hypoxia}

The increment of tolerance to hypoxia in each run was approximately in an arithmetic progression. The tolerance time increased significantly with each run. The average tolerance time of runs $1,2,3$, and 4 was $17.2 \pm 2.9$, $37.4 \pm 5.7,58.5 \pm 7.3$, and $78.7 \pm 7.9 \mathrm{~min}$, respectively (fig. 1), which was in accordance with our previous findings $[1,19]$.

\section{Expression of Ngb mRNA and Protein in Cerebral Cells}

The Ngb mRNA was analyzed by RT-PCR immediately at the end of each exposure to hypoxia. The relative abundance value of $\mathrm{Ngb}$ in each group was calculated by the $\mathrm{OD}$ ratio of $\mathrm{Ngb}$ to $\beta$-actin. The relative abundance values of group $\mathrm{H}_{1}(1.19 \pm 0.16)$ were significantly higher than those of group $\mathrm{H}_{0}(0.81 \pm 0.09 ; \mathrm{p}<0.05)$. Furthermore, after repetitive exposure to hypoxia, the $\mathrm{Ngb}$ values increased more at the mRNA level in group $\mathrm{H}_{4}$ $(1.48 \pm 0.31)$. A significant difference in the relative quantities of $\mathrm{Ngb}$ among the three groups was detected $(\mathrm{p}<0.05)$. The results for the RT-PCR products of $\mathrm{Ngb}$ and $\beta$-actin are shown in figure $2 \mathrm{a}$, and the relative abundance ratio of $\mathrm{Ngb}$ to $\beta$-actin is shown in figure $2 \mathrm{~b}$.

$\mathrm{Ngb}$ protein was detected in the three groups by Western blot (fig. 2c) using a goat polyclonal antibody (Santa

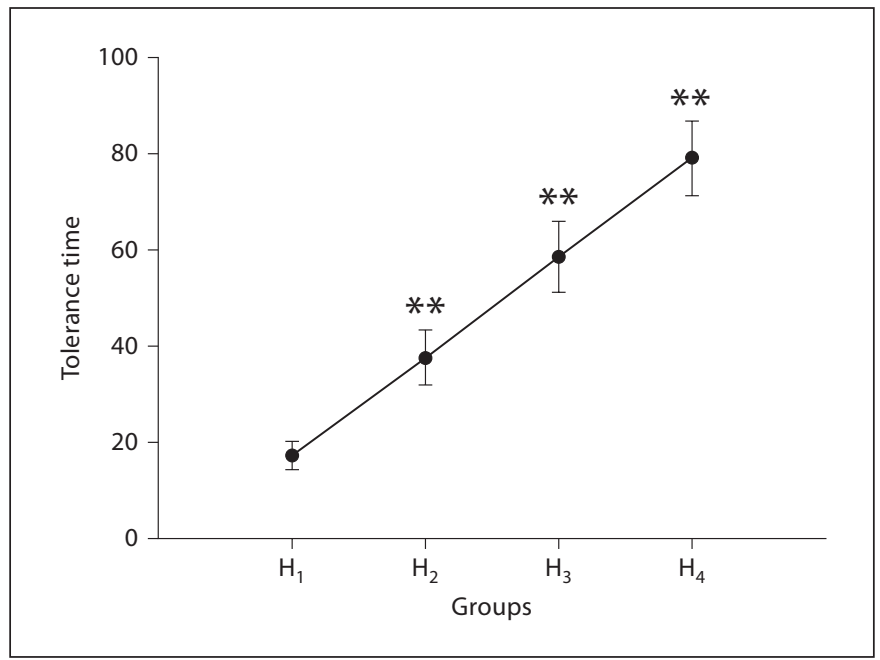

Fig. 1. Tolerance time in the different exposure runs $(n=30$; ${ }^{* *} \mathrm{p}<0.01$ as compared with the preceding runs).

Cruz Biotechnology). A faint band of about $17 \mathrm{kDa}$ was seen in group $\mathrm{H}_{0}$ while a more distinct band of $\mathrm{Ngb}$ was seen at the corresponding location in groups $\mathrm{H}_{1}$ and $\mathrm{H}_{4}$. The relative abundance value of $\mathrm{Ngb}$ in each group was calculated by the $\mathrm{OD}$ ratio of $\mathrm{Ngb}$ to $\beta$-actin. The relative abundance value of $\mathrm{Ngb}$ in group $\mathrm{H}_{0}$ is $0.25 \pm 0.09$. The relative abundance value of $\mathrm{Ngb}$ protein increased in group $\mathrm{H}_{1}(0.66 \pm 0.17)$ and markedly increased in group $\mathrm{H}_{4}(2.40 \pm 0.45)$. A significant difference in the relative abundance value of $\mathrm{Ngb}$ was seen among the three groups $(<0.01, \mathrm{n}=6)$ (fig. $2 \mathrm{~d})$.

\section{Tolerance of Ngb-Transformed SH-SY5Y Cells to Hypoxia}

When normal SH-SY5Y cells were exposed to 1\% oxygen, the number of dead cells was shown to increase by Hoechst and PI staining as the exposure duration lasted for $6 \mathrm{~h}$. Recombinant pEGFP-Ngb and vector pEGFP-N1 were then, respectively, transfected into cell SH-SY5Y. No apparent PI-stained and Hoechst-scattering cells were seen in most pEGFP-Ngb transformed SH-SY5Y cells after the Ngb-transformed SH-SY5Y cells were exposed to $1 \%$ oxygen for 6 h: $67.3 \%$ of them remained alive during and after exposure to hypoxia, whereas $83.2 \%$ of cells transfected with pEGFP-N1 were dead (fig. $3 \mathrm{a}-\mathrm{c}$ ). The cells transfected with pEGFP-Ngb or pEGFP-N1 showed different Ngb expression levels and different caspase-3/7 activity. Caspase activity decreased with increasing $\mathrm{Ngb}$ expression (fig. 4, 5). 

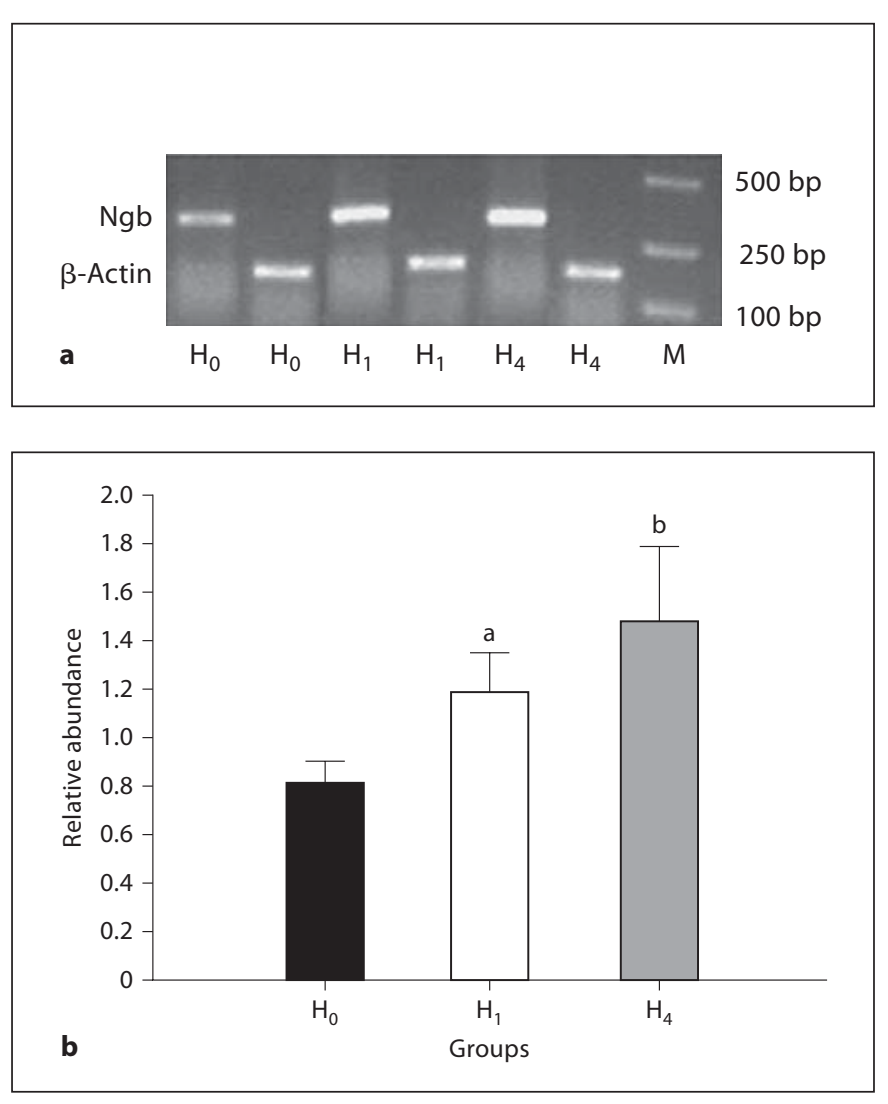

Fig. 2. Expression of Ngb in the cerebral cortex. a RT-PCR analysis of Ngb mRNA expression in mouse cerebral cortex; $\beta$-actin was used as control $(n=6)$. b Ratio of Ngb mRNA to $\beta$-actin mRNA in the $\mathrm{H}_{0}, \mathrm{H}_{1}$, and $\mathrm{H}_{4}$ groups $\left(\mathrm{n}=6,{ }^{\mathrm{a}} \mathrm{p}<0.05\right.$ vs. group
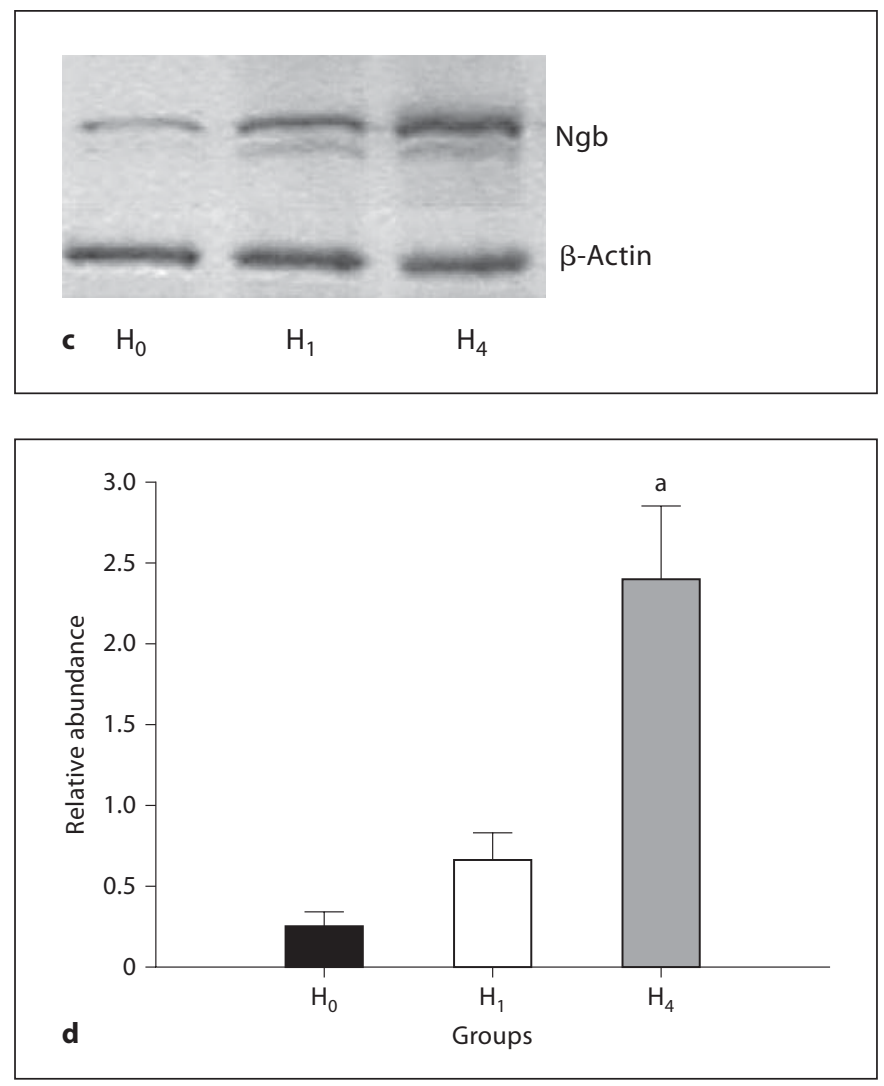

$\mathrm{H}_{0}$; ${ }^{\mathrm{b}} \mathrm{p}<0.05$ vs. groups $\mathrm{H}_{0}$ and $\mathrm{H}_{1}$ ). c Western blot analysis of $\mathrm{Ngb}$ protein expression in mouse cerebral cortex. $\mathbf{d}$ Ratio of Ngb protein to $\beta$-actin protein in the $\mathrm{H}_{0}, \mathrm{H}_{1}$, and $\mathrm{H}_{4}$ groups $(n=6$, ${ }^{\mathrm{a}} \mathrm{p}<0.01$ vs. groups $\mathrm{H}_{0}$ and $\mathrm{H}_{1}$.

\section{Discussion}

Oxygen is essential for life processes such as oxidative phosphorylation, with oxygen serving as an electron acceptor and producing ATP. It maintains intracellular environmental homeostasis through ATP-dependent pumping systems. Lacking oxygen, neurons are injured mainly because of ATP insufficiency [25]. I/HPC (or HPC) may protect neurons against damage under hypoxic conditions. Endogenous cellular adaptation triggered by HPC through an unclear mechanism is believed to be responsible for it. One prominent feature of cellular adaptation to hypoxia is increased expression of the new proteins contributing to neuroprotection [9]. Some of these proteins may protect neurons against hypoxia injury by decreasing the demand for oxygen and increasing oxygen supply. Lowering metabolic demand for oxygen is generally considered effective [26]. Our previous studies showed that gas/energy metabolism in the brain could be decreased by acute and repeated exposure to hypoxia in mice [19]. During exposure, some oxygen/supply/enhancing molecules which were upregulated such as VEGF can improve hypoxia tolerance [7]. Sun et al. [12] reported that Ngb expression is increased by neuronal hypoxia in vitro, and in vivo focal cerebral ischemia and neuronal survival after hypoxia reduced by Ngb expression are inhibited by an antisense oligodeoxynucleotide, but enhanced by Ngb overexpression. Thus, Ngb was induced by neuronal hypoxia and cerebral ischemia and could protect neurons against hypoxia. Similarly, transgenic mice overexpressing $\mathrm{Ngb}$ in multiple body tissues were resistant to cerebral and myocardial ischemia [27]. We hypothesized that $\mathrm{Ngb}$ might play a neuroprotective role in HPC mice because the protein was mainly expressed in neuronal tissue (brain and retina), has a relatively high affinity for oxygen $\left(\mathrm{P}_{50}\right.$ about $1 \mathrm{~mm} \mathrm{Hg}$ at $\left.37^{\circ} \mathrm{C}\right)$, and 


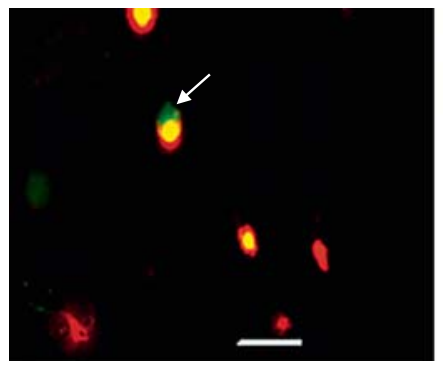

a

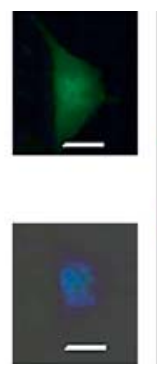

Hoechst

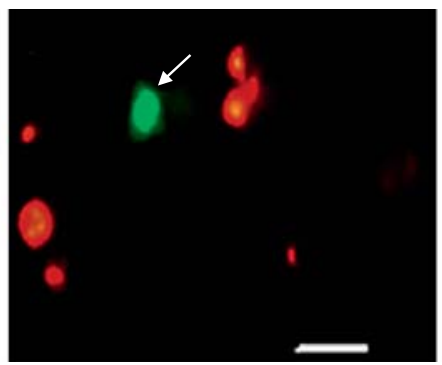

$\mathrm{Pl}$

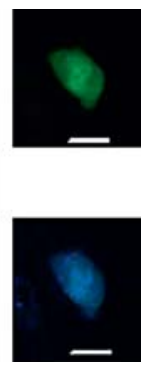

Hoechst

Fig. 3. Effect of Ngb overexpression on cell death. a pEGFP-N1- and b pEGFP-Ngb-transfected SH-SY5Y cells exposed to $1 \%$ oxygen for $6 \mathrm{~h}$. The arrow in $\mathbf{b}$ shows a living pEGFPNgb-transfected cell stained by Hoechst, but not PI, and the arrow in a shows a dead pEGFP-N1-transfected cell stained by both Hoechst and PI (PI: bar $=75 \mu \mathrm{m}$, Hoechst: bar $=25 \mu \mathrm{m})$. c Percentage of living and dead SH-SY5Y cells transfected with pEGFP-Ngb, or pEGFP-N1, or without plasmid. After $6 \mathrm{~h}$ of hypoxic injury, cells were stained with PI/ Hoechst, and the survival ratio of cells transfected with pEGFP-Ngb and pEGFP-N1 was measured as the ratio of cells carrying PI-unstained nuclei and GFP to cells with GFP; the survival ratio of cells not transfected (control) was measured as the ratio of cells with PI-unstained nuclei to all cells (each about 2,000 cells).

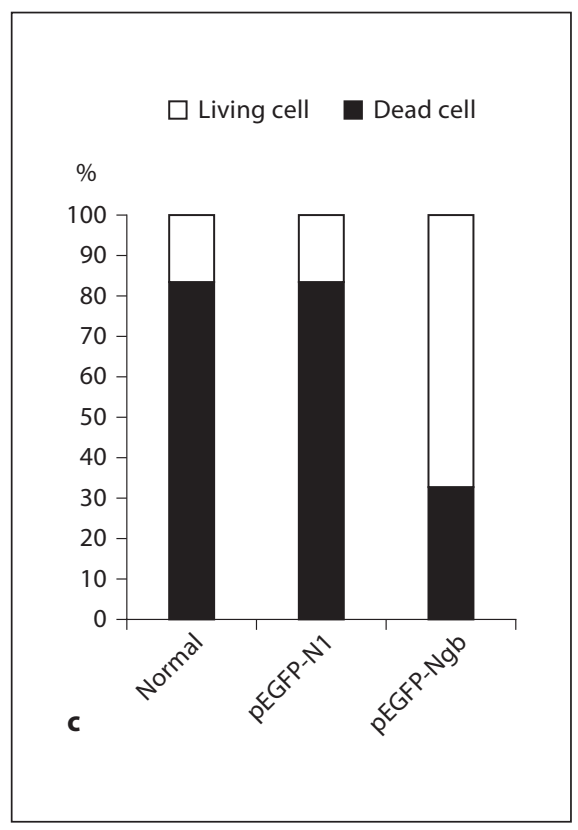

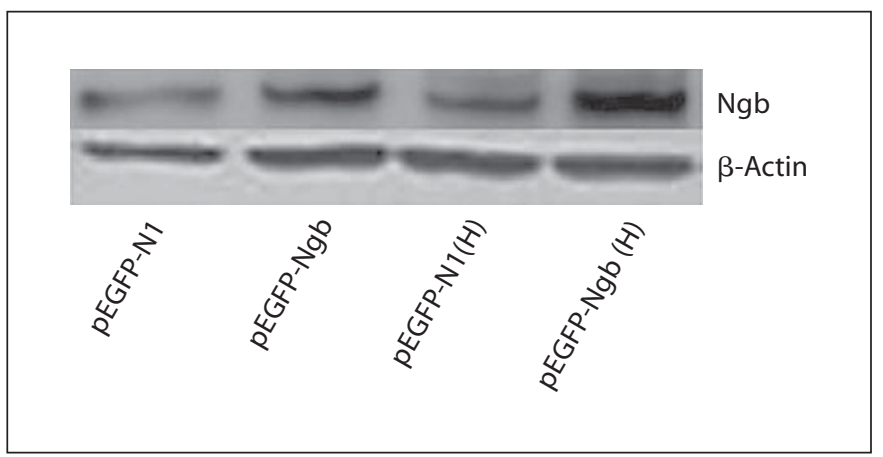

Fig. 4. Western blot analysis of the expression of $\mathrm{Ngb}$ protein in SH-SY5Y cells transfected with pEGFP-N1 or pEGFP-Ngb. Cells were exposed to hypoxia ( $1 \%$ oxygen for $6 \mathrm{~h}, \mathrm{H})$ or not.

could prevent hypoxia/ischemia injury in neurons in vivo and in vitro $[12,27,28]$.

$\mathrm{Ngb}$ is a member of the globin superfamily and is mainly expressed in the vertebrate brain and retina. Many researchers have reported increases in Ngb that protected the brain against hypoxia or ischemia, but the physiological role of Ngb has not been well understood, even though several putative functional roles have been

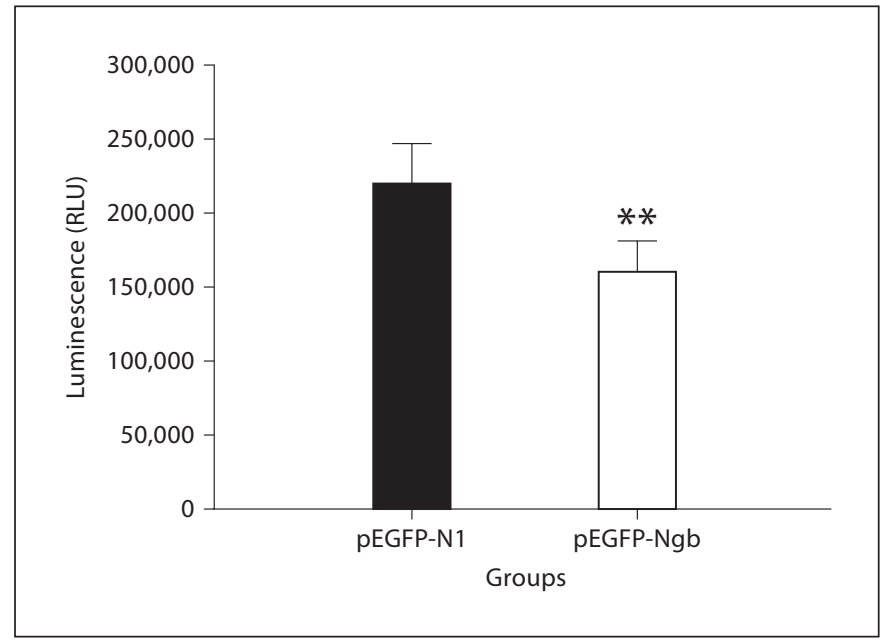

Fig. 5. Effect of Ngb overexpression (pEGFP-Ngb) on caspase 3/7 activity SH-SY5Y cells under hypoxia (1\% oxygen for $6 \mathrm{~h}$ ). RLU = Relative light units. $\mathrm{n}=8$; ${ }^{* *} \mathrm{p}<0.05$ vs. pEGFP-N1 group.

proposed. Ngb in the brain, similar to that of the retina, may bind oxygen and facilitate its delivery to mitochondria [29]. However, Ngb is present at a fairly low concentration in the brain (less than $0.01 \%$ of the protein content), compared with myoglobin in the heart (about 0.2 $\mathrm{mM}$ ) [30]. Because of the relatively high concentration of myoglobin in the heart and its role in facilitating the storage, transport, and intracellular diffusion of $\mathrm{O}_{2}$, the ma- 
jor function of $\mathrm{Ngb}$ in the brain was assumed to be different from that of myoglobin because of its very low concentration in the brain [18]. However, Reuss et al. [15] showed that Ngb mRNA was expressed in neuronal somata whose volume makes up only a small part of the total brain volume, and these authors suggested that local concentrations of $\mathrm{Ngb}$ within nerve cells can be quite high. Therefore, Ngb may greatly facilitate storage, transport, and intracellular diffusion of oxygen. As a heme protein, Ngb may bind with and scavenge nitric oxide. $\mathrm{Ngb}$ may be a hypoxia sensor or, as suggested recently, a sensor of the ratio of oxygen and nitric oxide levels [31]. $\mathrm{Ngb}$ may also be involved in MAPK pathways of phosphotidylinositol 3-kinase activation by interacting with G protein- $\alpha$ and promoting cell survival in the brain under conditions of oxidative stress such as ischemia and reperfusion [17].

Some studies have investigated whether Ngb is upregulated in response to ischemia or hypoxia [12, 32-34]. $\mathrm{Ngb}$ mRNA and protein can be detected under normoxic and hypoxic conditions in the brain, and Ngb mRNA and protein were up-regulated under hypoxic conditions $[12,32]$. In contrast with these data, other studies showed that Ngb mRNA was not regulated by exposure to hypoxia [33]. This discrepancy could be explained by the different hypoxic stimuli causing divergent effects on the $\mathrm{Ngb}$ gene. Indeed, this explanation was supported by the research report of Hundahl et al. [34], which showed that $\mathrm{Ngb}$ is upregulated only in the acute phase of hypoxia. To our knowledge, the change in Ngb in HPC mice has not been reported under acute repeated hypoxic conditions. We found that tolerance to hypoxia increased in mice acutely and repetitively exposed to autoprogressive hypoxia with increased Ngb mRNA and protein levels. This finding may indicate a functional role of $\mathrm{Ngb}$ in contributing to tolerance to hypoxia and to its protective effect during the acute and repeated hypoxia.

It remains uncertain whether Ngb is actually controlled by the major regulator of cellular hypoxia response known as hypoxia-inducible factor-1 (HIF-1). It has been suggested that potential hypoxia responsive elements (HREs) were found upstream of the Ngb gene in mice [12]. We found that Ngb mRNA and protein expressed in the $\mathrm{H}_{0}, \mathrm{H}_{1}$ and $\mathrm{H}_{4}$ groups were increased in group $\mathrm{H}_{1}$ and markedly increased in group $\mathrm{H} 4$. Our previous study revealed that HIF- $1 \alpha$ protein level and HIF-1 DNA binding activities increased in group $\mathrm{H}_{1}$ mice and markedly increased in group $\mathrm{H}_{4}$ mice as well [7]. Changes in Ngb mRNA and protein level paralleling HIF-1 $\alpha$ protein level and HIF-1 DNA binding activity could be explained by the $5^{\prime}$-untranslated region of Ngb containing one or several copies of HREs. However, a comparative study of mouse and human Ngb genes did not show any conservation of HREs that would permit induction by HIF-1 [14]. Transcription factors other than HIF-1 may also regulate $\mathrm{Ngb}$ under conditions of hypoxia in our model. Fordel et al. [35] speculated that HIF-2 might play an important role in inducing $\mathrm{Ngb}$ expression.

To further test the protective effect of Ngb in acute hypoxia, we transfected full-length mouse pEGFP-Ngb expression vectors into human SH-SY5Y neuroblastoma cells, which are often used as a model in hypoxia and anoxia experiments [36]. Cells overexpressing Ngb showed increased tolerance to severe hypoxia reflected by decreased cell death and caspase-3/7 activity. Fordel et al. [21] showed that under anoxic conditions SH-SY5Y cells grew very similarly to those under normoxia, and that oxygen and glucose deprivation was lethal to SH-SY5Y cells. By contrast, we observed significant death of SH-SY5Y cells after short exposure ( $6 \mathrm{~h}$ ) to $1 \%$ oxygen without glucose deprivation. The discrepancy may indicate that a tiny difference in experimental conditions can lead to significant differences in results and underscores the limitations of in vitro models. Although there exists a difference in experimental treatment, the results reported here were similar to those obtained by Fordel et al. [21], who also demonstrated an increased ratio of live cells expressing $\mathrm{Ngb}$ after a period of oxygen and glucose deprivation $(16 / 24 \mathrm{~h})$. Although our study largely supports that Ngb could increase tolerance to acute hypoxia, other authors have found no significant changes in Ngb expression in the adult murine brain in response to chronic $10 \%$ and acute $7.6 \%$ oxygen exposure $[33,34]$. Therefore, $\mathrm{Ngb}$ might have diverse functional roles under different conditions of hypoxia. Future use of other biologic technologies, including transgenic strategies [27], would be useful to further define the function of Ngb in the brain in hypoxia/ ischemia insults. Our results suggest the existence of endogenous neuroprotective mechanisms of Ngb. Understanding how $\mathrm{Ngb}$ confers neuronal protection might help improve the treatment of hypoxic/ischemic diseases.

\section{Acknowledgments}

This project was supported by the National Natural Science Foundation of China (No. 39670271), Beijing Natural Science Foundation (No. 7962009), China Postdoctoral Science Foundation (No. 20080430851) and Inner Mongolia Educational Research Foundation (No. NJ06011). We thank Dr. Jinping Li and Ms. Laura Heraty for their language-editing assistance. 


\section{References}

1 Lu G, Ding D, Shi M: Acute adaptation of mice to hypoxic hypoxia. Biol Signals Recept 1999;8:247-255.

$\checkmark 2$ Khaspekov L, Shamloo M, Victorov I, Wieloch T: Sublethal in vitro glucose-oxygen deprivation protects cultured hippocampal neurons against a subsequent severe insult. Neuroreport 1998;9:1273-1276.

>3 Cantagrel S, Krier C, Ducrocq S, Bodard S, Payen V, Laugier J, Guilloteau D, Chalon S: Hypoxic preconditioning reduces apoptosis in a rat model of immature brain hypoxiaischaemia. Neurosci Lett 2003;347:106-110.

$\checkmark 4$ Kitagawa K, Matsumoto M, Tagaya M, Hata R, Ueda H, Niinobe M, Handa N, Fukunaga R, Kimura K, Mikoshiba K, et al: 'Ischemic tolerance' phenomenon found in the brain. Brain Res 1990;528:21-24.

$\checkmark 5$ Murry CE, Jennings RB, Reimer KA: Preconditioning with ischemia: a delay of lethal cell injury in ischemic myocardium. Circulation 1986;74:1124-1136.

6 Lu GW, Liu HY: Downregulation of nitric oxide in the brain of mice during their hypoxic preconditioning. J Appl Physiol 2001; 91:1193-1198.

7 Shao G, Gao CY, Lu GW: Alterations of hypoxia-inducible factor-1 alpha in the hippocampus of mice acutely and repeatedly exposed to hypoxia. Neurosignals 2005; 14 : 255-261.

8 Niu C, Li J, Cui X, Han S, Zu P, Li H, Xu Q: Changes in cPKC isoform-specific membrane translocation and protein expression in the brain of hypoxic preconditioned mice. Neurosci Lett 2005;384:1-6.

$\checkmark 9$ Wenger RH: Cellular adaptation to hypoxia: $\mathrm{O}_{2}$-sensing protein hydroxylases, hypoxiainducible transcription factors, and $\mathrm{O}_{2}$-regulated gene expression. FASEB J 2002;16: 1151-1162.

10 Barone FC, White RF, Spera PA, Ellison J, Currie RW, Wang X, Feuerstein GZ: Ischemic preconditioning and brain tolerance: temporal histological and functional outcomes, protein synthesis requirement, and interleukin-1 receptor antagonist and early gene expression. Stroke 1998;29:1937-1950.

-11 Burmester T, Weich B, Reinhardt S, Hankeln $\mathrm{T}$ : A vertebrate globin expressed in the brain. Nature 2000;407:520-523.

-12 Sun Y, Jin K, Mao XO, Zhu Y, Greenberg DA: Neuroglobin is up-regulated by and protects neurons from hypoxic-ischemic injury. Proc Natl Acad Sci USA 2001;98:15306-15311.
13 Sun Y, Jin K, Peel A, Mao XO, Xie L, Greenberg DA: Neuroglobin protects the brain from experimental stroke in vivo. Proc Natl Acad Sci USA 2003;100:3497-3500.

14 Wystub S, Laufs T, Schmidt M, Burmester T, Maas U, Saaler-Reinhardt S, Hankeln T, Reuss S: Localization of neuroglobin protein in the mouse brain. Neurosci Lett 2003;346: $114-116$.

15 Reuss S, Saaler-Reinhardt S, Weich B, Wystub S, Reuss MH, Burmester T, Hankeln T: Expression analysis of neuroglobin mRNA in rodent tissues. Neuroscience 2002;115: 645-656.

16 Fago A, Mathews AJ, Dewilde S, Moens L, Brittain T: The reactions of neuroglobin with CO: evidence for two forms of the ferrous protein. J Inorg Biochem 2006;100:13391343.

17 Wakasugi K, Nakano T, Morishima I: Oxidized human neuroglobin acts as a heterotrimeric g $\alpha$ protein guanine nucleotide dissociation inhibitor. J Biol Chem 2003;278: 36505-36512.

18 Brunori M, Giuffre A, Nienhaus K, Nienhaus GU, Scandurra FM, Vallone B: Neuroglobin, nitric oxide, and oxygen: functional pathways and conformational changes. Proc Nat Acad Sci USA 2005; 102:8483-8488.

19 Lu GW, Cui XY, Zhao BM: Alteration of oxygen consumption and energy metabolism during repetitive exposure of mice to hypoxia. Neurochem Res 1999;24:625-628.

20 Bergeron M, Gidday JM, Yu AY, Semenza GL, Ferriero DM, Sharp FR: Role of hypoxiainducible factor-1 in hypoxia-induced ischemic tolerance in neonatal rat brain. Ann Neurol 2000;48:285-296.

21 Fordel E, Thijs L, Martinet W, Schrijvers D, Moens L, Dewilde S: Anoxia or oxygen and glucose deprivation in SH-SY5Y cells: a step closer to the unraveling of neuroglobin and cytoglobin functions. Gene 2007;398:114122.

22 Laufs TL, Wystub S, Reuss S, Burmester T, Saaler-Reinhardt S, Hankeln T: Neuron-specific expression of neuroglobin in mammals. Neurosci Lett 2004;362:83-86.

23 Jin KL, Mao XO, Greenberg DA: Vascular endothelial growth factor rescues HN33 neural cells from death induced by serum withdrawal. J Mol Neurosci 2000;14:197203.

24 Shi LC, Wang HY, Friedman E: Involvement of platelet-activating factor in cell death induced under ischemia/postischemia-like conditions in an immortalized hippocampal cell line. J Neurochem 1998;70:1035-1044.

-25 Bickler PE, Donohoe PH: Adaptive responses of vertebrate neurons to hypoxia. J Exp Biol 2002;205:3579-3586.
26 Zwemer CF, Song MY, Carello KA, D’Alecy LG: Strain differences in response to acute hypoxia: CD-1 versus C57BL/6J mice. J Appl Physiol 2007;102:286-293.

27 Khan AA, Wang Y, Sun Y, Mao XO, Xie L, Miles E, Graboski J, Chen S, Ellerby LM, Jin K, Greenberg DA: Neuroglobin-overexpressing transgenic mice are resistant to cerebral and myocardial ischemia. Proc Natl Acad Sci USA 2006;103:17944-17948.

28 Dewilde S, Ebner B, Vinck E, Gilany K, Hankeln T, Burmester T, Kreiling J, Reinisch C, Vanfleteren JR, Kiger L, Marden MC, Hundahl C, Fago A, Van Doorslaer S, Moens L: The nerve hemoglobin of the bivalve mollusc Spisula solidissima: molecular cloning, ligand binding studies, and phylogenetic analysis. J Biol Chem 2006;281:5364-5372.

29 Schmidt M, Giessl A, Laufs T, Hankeln T, Wolfrum U, Burmester T: How does the eye breathe? Evidence for neuroglobin-mediated oxygen supply in the mammalian retina. J Biol Chem 2003;278:1932-1935.

30 Wittenberg JB: Myoglobin-facilitated oxygen diffusion: role of myoglobin in oxygen entry into muscle. Physiol Rev 1970;50:559636.

31 Brunori M, Vallone B: A globin for the brain. FASEB J 2006;20:2192-2197.

-32 Li RC, Lee SK, Pouranfar F, Brittian KR, Clair HB, Row BW, Wang Y, Gozal D: Hypoxia differentially regulates the expression of neuroglobin and cytoglobin in rat brain. Brain Res 2006;1096:173-179.

33 Mammen PP, Shelton JM, Goetsch SC, Williams SC, Richardson JA, Garry MG, Garry DJ: Neuroglobin, a novel member of the globin family, is expressed in focal regions of the brain. J Histochem Cytochem 2002;50:15911598

34 Hundahl C, Stoltenberg M, Fago A, Weber RE, Dewilde S, Fordel E, Danscher G: Effects of short-term hypoxia on neuroglobin levels and localization in mouse brain tissues. Neuropathol Appl Neurobiol 2005;31:610617.

35 Fordel E, Geuens E, Dewilde S, Rottiers P, Carmeliet P, Grooten J, Moens L: Cytoglobin expression is upregulated in all tissues upon hypoxia: an in vitro and in vivo study by quantitative real-time PCR. Biochem Biophys Res Commun 2004;319:342-348.

>36 Prabhakaran K, Sampson DA, Hoehner JC: Neuroblastoma survival and death: an in vitro model of hypoxia and metabolic stress. J Surg Res 2004;116:288-296. 